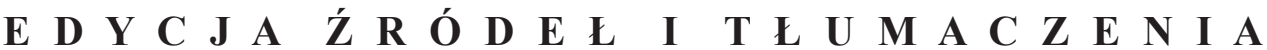

Saeculum Christianum

t. XXVII $\cdot 2 / 2020$

s. $219-224$

\author{
MARCIN A. KLEMENSKI
}

Uniwersytet Jagielloński

\section{WYKAZ KONWERTYTÓW Z LAT 1778-1779 Z ARCHIWUM KOŚCIOLA ŚW. MARKA W KRAKOWIE - EDYCJA ŹRÓDŁOWA}

$\mathrm{W}$ iek XVIII był okresem świetności dla Kościoła katolickiego w I Rzeczypospolitej: powstało wtedy wiele nowych fundacji zakonnych, rozwijały się stacje misyjne na wschodnich rubieżach kraju i prowadzono akcję nawracania na katolicyzm. W późniejszym okresie było już to utrudnione ze względu na realia polityczne, które zmieniły się po rozbiorach Polski.

Jak słusznie zauważył Waldemar Kowalski, temat konwersji na katolicyzm był często poruszany w licznych opracowaniach omawiających problemy wyznaniowe w Rzeczypospolitej ${ }^{1}$. Problem ten znalazł odzwierciedlenie w badaniach szczegółowych nad dziejami poszczególnych wspólnot zakonnych, np. jezuitów ${ }^{2}$, franciszkanów-reformatów ${ }^{3}$, bernardynów ${ }^{4}$, kapucynów ${ }^{5}$. Największą popularnością cieszyły się badania nad konwersją Żydów ${ }^{6}$. Omówiono również w literaturze problem konwersji na katolicyzm w środowiskach protestanckich ${ }^{7}$. Jedyna pełna monografia o zakonie kanoników regularnych od pokuty pióra

\footnotetext{
W. Kowalski, Małopolscy franciszkanie-reformaci a konwersje na katolicyzm w dobie przedrozbiorowej, w: Ludzie, Kościól, wierzenia. Studia z dziejów kultury i społeczeństwa Europy Środkowej (średniowiecze - wczesna epoka nowożytna), red. W. Iwańczak, S.K. Kuczyński, Warszawa 2001, s. 151. Tam omówienie starszej literatury przedmiotu.

2 J. Flaga, Działalność duszpasterska zakonów w drugiej połowie XVIII wieku, Lublin 1986, s. 231-252; S. Kościelak, Jezuici w trzech wielkich miastach pruskich w XVI-XVIII w., „Hereditas Monasteriorum”, 3/2013, s. 155-187; idem, Konwertyci elbląscy w świetle jezuickiego Fructus missionis z XVIII wieku, „Rocznik Elbląski”, 20/2006, s. 183-192; J. Wojtkowski, Konwertyci w kronice jezuitów malborskich 1647-1744, w: Jezuici w Malborku a życie religijne na terytorium diecezji pomezańskiej w okresie nowożytnym, red. J. Hochleitner, Malbork 2014, s. 121-132; R. Panfil, Działalność misyjna jezuitów rezydencji malborskiej w świetle wykazu konwertytów z l. 1662-1679, „Orientalia Christiana Cracoviensia”, 10/2018, s. 47-109.

3 W. Kowalski, Małopolscy franciszkanie-reformaci..., op. cit., s. 151-172.

4 J. Flaga, Działalność duszpasterska zakonów..., op. cit., s. 232.

5 Z. Komosiński, Próby osiedlenia się zakonu braci mniejszych kapucynów na Śląsku w XVII wieku, „Prawo Kanoniczne: Kwartalnik Prawno-historyczny", 18/1975, s. 195-243.

$6 \quad$ A. Kaźmierczyk, Rodziłem się Żydem ... Konwersje Żydów w Rzeczypospolitej XVII-XVIII wieku, Kraków 2015. Publikacja ta jest owocem kilkuletniego projektu badawczego „Jewish Apostasy in Eearly modern Polish-Lithuanian Commonwealth" i obecnie jest najpełniejszym opracowaniem dotyczącym tego problemu, świetnie jest tam omówiona starsza literatura przedmiotu.

7 B. Rok, Kościól katolicki wobec innowierców w Rzeczypospolitej czasów saskich. Problemy ujednolicania społeczeństwa w państwie wielonarodowym i wielowyznaniowym, „Kultura - Historia - Globalizacja”, 5/2009, s. 107-118; S. Kościelak, Katolicy w protestanckim Gdańsku od drugiej połowy XVI do końca XVIII wieku, Gdańsk 2012.
} 
Andrzeja Bruździńskiego niestety nie naświetla problemów związanych z akcją misyjną kanoników ${ }^{8}$.

W zakonnych środowiskach Małopolski i Pomorza zbierano spisy konwertytów. Wiele z nich nie doczekało się jeszcze edycji źródłowych ${ }^{9}$. Dotychczas edytowano spisy konwertytów związanych z franciszkańskimi klasztorami w Pińczowie i w Stopnicy ${ }^{10}$, jak i z placówką jezuicką w Malborku ${ }^{11}$. Ta niewielka liczba edycji spisów konwertytów skłania do tego, żeby podjąć trud wydania niewielkiego źródła dotyczącego konwertytów przyjętych do Kościoła katolickiego przez kanonika od pokuty Fortunata Dytryńskiego w 1. 1778-1779. Jak również warto wydać ze względu na to, że jest to jedyne dotychczas znane świadectwo udziału kanoników od pokuty w akcji rekatolizacji.

W literaturze prezentowany jest często pogląd, że zakon kanoników od pokuty pełnił funkcje misyjne na terenie chrystianizowanej Litwy od XIV wieku ${ }^{12}$ - jednak nie zbadano dokładnie misyjnej działalności kanoników ani w średniowieczu, ani w okresie późniejszym, mimo że posiadali placówki na trudnym terenie, gdzie ścierały się wpływy katolicyzmu i prawosławia, a od XVI wieku wyznań ewangelickich. Trudnością w tych badaniach jest fakt, że po kasacie klasztorów kanonickich i wymarciu zakonników materiał źródłowy został rozproszony.

Podstawą edycji jest rękopis przechowywany w archiwum kościoła św. Marka, znajdującym się przy Bibliotece Instytutu Liturgicznego Uniwersytetu Papieskiego Jana Pawła II w Krakowie. Został on odnaleziony w trakcie porządkowania zbiorów archiwalnych kościoła św. Marka w Krakowie i nie posiada jeszcze sygnatury. Nie był dotychczas notowany w literaturze przedmiotu ${ }^{13}$. Oprawiony jest w skórę, posiada 158 sfoliowanych stron i wymaga prac konserwatorskich. Składki są już od samego początku użytkowania zszyte. Karty posiadają wymiary $25,5 \times 10 \mathrm{~cm}$. W rękopisie znajdują się metryki przyjęć do habitu z lat 1638-1792 (k. 1-41v) i pierwszej profesji z lat 1638-1793 (k. 71-104v) $)^{14}$, wykazy generałów zakonu (k. 152-153), prepozytów-infułatów klasztoru w Widzieniszkach (k. 155) oraz na ostatniej stronie notatka o wyznaniu wiary 4 osób w kościele św. Marka z 1. 1778-1779 (k. 158v). Reszta kart jest niezapisana (k. 42-70v; 105-151v; 153v-154v; 155v-158) ${ }^{15}$.

\footnotetext{
A. Bruździński, Kanonicy od pokuty na ziemiach polskich, Kraków 2003.

9 Np. Cathalogum Neoconversorum ad fidem Catholicam, przechowywany w Archiwum ks. Misjonarzy w Krakowie.

10 W. Kowalski, Pińczowski spis konwertytów XVII-XIX wieku, „Nasza Przeszłość”, 73/1990, s. 5-33; idem, Stopnicki rejestr konwertytów XVII-XIX w., „Nasza Przeszłość”, 76/1991, s. 193-294. Omówione w: idem, Małopolscy franciszkanie reformaci..., op. cit., , s. 151-172.

11 R. Panfil, Działalność misyjna..., op. cit., s. 87-106.

12 T.M. Trajdos, Krakowscy ,, markowie” za panowania Władysława II Jagielly (1386-1434), ,Studia Historyczne", 25/1982, nr 3-4, s. 373-374, 385-386; idem, Najstarsze fundacje dla kanoników regularnych od pokuty w diecezji wileńskiej, „Nasza Przeszłość”, 119/2013, s. 21-66; A. Bruździński, Kanonicy od pokuty..., op. cit., s. 187.

13 R. Majkowska, Zarys dziejów i zawartości archiwum kościoła św. Marka w Krakowie, „Nasza Przeszłość”, 71/1989, s. 137-145; eadem, Bractwo św. Zofii w dokumentach archiwalnych - krótkie spojrzenie na dzieje archiwum, w: Bractwo św. Zofii: 600 lat istnienia, red. M. Łużna, J. Machniak, Kraków 2010, s. 37-48; A. Bruździński, Archiwa i źródła historyczne do zniesionego Zakonu Kanoników Regularnych od Pokuty, w: Archiwa w nowoczesnym społeczeństwie. Pamiętnik V Powszechnego Zjazdu Archiwistów Polskich, Olsztyn 6-8 września 2007 r., red. K. Poraziński, K. Stryjkowski, Warszawa 2008, s. 213-226.

14 Planowana jest edycja metryki przyjęć do habitu i pierwszej profesji.

15 Szerszy opis rękopisu zob. B. Bonar, M. Klemenski, Nieznane źródła do dziejów zakonu kanoników regularnych od pokuty - wykazy przełożonych generalnych oraz prepozytów-infułatów klasztoru w Widzieniszkach-edycja źródłowa, „Nasza Przeszłość”, 132/2020, s. 79-94.
} 
Autorem zapisek o konwertytach był sam Fortunat Dytryński, świadczy o tym sformułowanie restitutus per me A.R.D. Fortunatum Dytriński. Przyjął habit kanonika regularnego od pokuty 15 grudnia $1761 \mathrm{r}^{16}$, tym samym zaczynając kanoniczną formację w tymże zgromadzeniu; pierwszą profesję złożył 21 grudnia 1762 r. ${ }^{17}$, zaś 26 lutego 1763 r. przyjął święcenia niższe, a święcenia kapłańskie uzyskał 20 września 1766 r. Pełnił obowiązki kustosza kościoła św. Marka w Krakowie, później, w 1. 1777-1780, był wzmiankowany jako podprzeor konwentu św. Marka ${ }^{18}$. Nieznane są obecnie żadne bliższe informacje biograficzne o tej postaci.

Prawdopodobnie informacje o konwersjach były zapisane niedługo po tych uroczystościach, świadczy o tym chociażby brak porządku chronologicznego - najpierw wpisano sierpniową konwersję Krzysztofa Bernekera, a później wiosenną konwersję Elżbiety de Pacin. Miejsce zapisków - księga metryki zakonnej, świadczyć może o tym, że były to jednorazowe wydarzenia w dziejach konwentu, jednak na tyle ważne, by je poświadczyć. W trakcie kwerendy nie znaleziono żadnych innych spisów konwertytów prowadzonych przez krakowskich kanoników od pokuty.

Niniejsze źródło przynosi informację o czterej konwersjach w krakowskim kościele św. Marka: Krzysztofa Bernekera pochodzącego z Cesarstwa Habsburskiego, Elżbiety de Pacin z Węgier, Samuela Erlicha ze Śląska wrocławskiego i Karola Schmida z Prus. Dla każdego z tych konwertytów urządzona była oddzielna uroczystość, znane są terminy trzech konwersji - 15 sierpnia, 5 niedziela po Wielkanocy 1778 r. oraz 2 lutego 1779 r. (wtedy przyjęto wyznanie wiary od dwóch konwertytów). Przyjmującym konwersję był Fortunat Dytryński, który był podprzeorem klasztoru św. Marka, zaś świadkami byli mieszczanie krakowscy - Jan Heisler, Michał Zawalski, Józef Kuczerowicz, Antoni Kawiński - którzy mogli być przypuszczalnie członkami bractwa św. Zofii, jednak księga bracka nie notuje tych nazwisk ${ }^{19}$.

Niestety, nie wiadomo, jakiego pierwotnie byli wyznania ci konwertyci, jednak należy przypuszczać, że byli chrześcijanami, na co wskazuje fakt, że wystarczyło, by złożyli wyznanie wiary i nie było uroczystości chrzcielnych ${ }^{20}$. Przypadek Karola Schmida pozwala przypuszczać, że był pierwotnie katolikiem, który popadł w jakieś błędy (errores) i po ich publicznym odwołaniu wrócił w szeregi Kościoła katolickiego.

$$
* * *
$$

Edycja źródłowa została przygotowana według zasad instrukcji wydawniczej dla źródeł nowożytnych opracowanych przez Kazimierza Lepszego ${ }^{21}$. Zachowane zostały cechy ówczesnego języka łacińskiego, przy równoczesnej modernizacji pisowni. Paginację rękopisu

\footnotetext{
16 Archiwum kościoła św. Marka w Krakowie (dalej AKMKrk), Metrica Fratrum de Poenitentia Beatorum Martyrum Canonicorum Regularium sub Regula Sancti Augustini militantium, k. 32.

17 AKMKrk, Metrica Fratrum, k. 99v.

18 A. Bruździński, Kanonicy regularni..., op. cit., s. 371.

19 AKMKrk, Książka Arcybractwa S. Zofii exystującego przy kościele świętego Marka Ewangelisty w Krakowie.

20 Poświadcza to kwerenda w księgach chrztów parafii Mariackiej w Krakowie za lata 1778-1779, zob.: Archiwum Bazyliki Mariackiej w Krakowie, sygn. 376, Liber metrices baptisatorum eccl. Paroch. BVM in circulo Cracoviensis ab 1773. W tych latach poświadczone są przynajmniej trzy chrzty konwertytów z judaizmu, które odbyły się w krakowskich kościołach reformatów i kapucynów, zob. ABMKrk, sygn. 376, Liber metrices, k. 211 v, $237,241$.

21 K. Lepszy, Instrukcja wydawnicza dla źródet historycznych od XVI do pot. XIX w., Warszawa 1953.
} 
umieszczono w edycji w nawiasach kwadratowych [ ], a koniec strony oryginalnego tekstu zaznaczono dwiema ukośnymi kreskami //. Objaśnienia osób i nazw występujących w tekście źródłowym podano w przypisach rzeczowych.

\section{Edycja źródłowa}

[k. $158 \mathrm{v}]$

Anno Domini 1778 Die 15 Augusti Chrystophorus Berneker ${ }^{22}$ ex Imperio deposuit Profesionem Fidei Catholicae in Ecclesia S. Marci Evang. in manibus A.R.P. Fortunati Dytriński ${ }^{23}$ assistentis Generalis coram testibus D. Joanne Heisler ${ }^{24}$ et Michaele Zawalski ${ }^{25}$ Civibus Cracoviensis.

Eodem anno Dominica 5ta post Pascha ${ }^{26}$ Elisabetha de Pacin ${ }^{27}$ ex Hungaria oriunda in eadem Ecclesia professa est Fidem Catholicam in manibus ejusdem A.R.P. Fortunati Dytrinski assistentis coram testibus NN. DD. Josepho Kuczerowicz ${ }^{28}$ et Zawalski.

Anno 1779 Die 2 Februaris in festo Annuntiacionis B.V.M. Samuel Erlich ${ }^{29}$ ex Silesia Wratislaviensis oriundus in eadem Ecclesia S. Marci Evang: professus est Fidem Catholicam servatis servandis in manibus ejusdem A.R.P. Fortunati Dytrinski assistentis et praepositi Cracoviensis, coram testibus NN. DD. Antonio Kawinski ${ }^{30}$ et Joanne Heisler Civibus Cracoviensis.

Anno eodem Die: in Ecclesia S. Marci Carolus Schmid ${ }^{31}$ ex Borussia oriundus errores suae Sectae revocavit ac Fidem Catholicam publice professus, ab haeresi servatis servandis in foro utroqus absolutus et comunioni S. Matris Ecclesia restitutus per me A.R.D. Fortunatum Dytriński pro tunc Assistentem Generalis ac Superiorem Cracoviensis praesentibus testibus NN. DD. Joanne Heisler Cive Cracoviensis et D. Ferdinando de Dan ${ }^{32}$ Officiale Regio Majestatis Polonia. //

\footnotetext{
22 Postać nieznana w dotychczasowej literaturze.

23 Fortunat Dytriński wstąpił do zakonu kanoników od pokuty przed 1763 r., święcenia kapłańskie uzyskał w 1766 r., w 1769 r. kustosz kościoła św. Marka w Krakowie, w 1. 1777-1780 podprzeor konwentu św. Marka i asystent generalny, zob. A. Bruździński, Kanonicy regularni..., op. cit., s. 371.

24 Postać nieznana w dotychczasowej literaturze.

25 Postać nieznana w dotychczasowej literaturze.

2624 maja 1778 r., zob. B. Włodarski, Chronologia polska, Warszawa 1957, s. 404.

27 Postać nieznana w dotychczasowej literaturze.

28 Józef Antoni Kuczerowicz, radca i kupiec win, właściciel kamienicy przy ul. Sławkowskiej 7, zmarł w 1795 r., zob. A. Chmiel, Domy krakowskie: ulica Stawkowska, cz. 1, Kraków 1931, „Biblioteka Krakowska”, nr 75, s. 52.=

29 Postać nieznana w dotychczasowej literaturze.

30 Postać nieznana w dotychczasowej literaturze.

31 Postać nieznana w dotychczasowej literaturze.

32 Postać nieznana w dotychczasowej literaturze.
} 


\section{Źródla rękopiśmienne}

Archiwum kościoła św. Marka w Krakowie:

BS. Metrica Fratrum de Poenitentia Beatorum Martyrum Canonicorum Regularium sub Regula Sancti Augustini militantium.

BS. Książka Arcybractwa S. Zofii exystującego przy kościele świętego Marka Ewangelisty w Krakowie.

\section{Bibliografia}

Bonar B., Klemenski M., Nieznane źródła do dziejów zakonu kanoników regularnych od pokuty - wykazy przełożonych generalnych oraz prepozytów-infułatów klasztoru $w$ Widzieniszkach - edycja źródłowa, „Nasza Przeszłość”, 132/2020, s. 79-94.

Bruździński A., Archiwa i źródła historyczne do zniesionego Zakonu Kanoników Regularnych od Pokuty, w: Archiwa w nowoczesnym społeczeństwie. Pamiętnik V Powszechnego Zjazdu Archiwistów Polskich, Olsztyn 6-8 września 2007 r., red. K. Poraziński, K. Stryjkowski, Warszawa 2008, s. 213-226.

Bruździński A., Kanonicy od pokuty na ziemiach polskich, Kraków 2003.

Chmiel A., Domy krakowskie: ulica Stawkowska, cz. 1, Kraków 1931, „Biblioteka Krakowska", nr 75.

Flaga F., Działalność duszpasterska zakonów w drugiej połowie XVIII wieku, Lublin 1986.

Kaźmierczyk A., Rodziłem się Żydem... Konwersje Żydów w Rzeczypospolitej XVII-XVIII wieku, Kraków 2015.

Komosiński Z., Próby osiedlenia się zakonu braci mniejszych kapucynów na Śląsku w XVII wieku, „Prawo Kanoniczne: Kwartalnik Prawno-historyczny”, 18/1975, s. 195-243.

Kościelak S., Jezuici $w$ trzech wielkich miastach pruskich w XVI-XVIII w., „Hereditas Monasteriorum", 3/2013, s. 155-187.

Kościelak S., Katolicy w protestanckim Gdańsku od drugiej połowy XVI do końca XVIII wieku, Gdańsk 2012.

Kościelak S., Konwertyci elbląscy w świetle jezuickiego Fructus missionis z XVIII wieku, „Rocznik Elbląski”, 20/2006, s. 183-192.

Kowalski W., Małopolscy franciszkanie reformaci a konwersje na katolicyzm $w$ dobie przedrozbiorowej, w: Ludzie, Kościól, wierzenia. Studia z dziejów kultury i społeczeństwa Europy Środkowej (średniowiecze - wczesna epoka nowożytna), red. W. Iwańczak, S.K. Kuczyński, Warszawa 2001, s. 151-172.

Kowalski W., Pińczowski spis konwertytów XVII-XIX wieku, „Nasza Przeszłość”, 73/1990, s. 5-33.

Kowalski W., Stopnicki rejestr konwertytów XVII-XIX w., „Nasza Przeszłość”, 76/1991, s. 193-294.

Lepszy K., Instrukcja wydawnicza dla źródet historycznych od XVI do poł. XIX w., Warszawa 1953.

Majkowska R., Bractwo św. Zofii w dokumentach archiwalnych - krótkie spojrzenie na dzieje archiwum, w: Bractwo św. Zofii: 600 lat istnienia, red. M. Lużna, J. Machniak, Kraków 2010, s. 37-48.

Majkowska R., Zarys dziejów i zawartości archiwum kościoła św. Marka w Krakowie, „Nasza Przeszłość", 71/1989, s. 137-145. 
Panfil R., Działalność misyjna jezuitów rezydencji malborskiej w świetle wykazu konwertytów z l. 1662-1679, „Orientalia Christiana Cracoviensia”, 10/2018, s. 47-109.

Rok B., Kościół katolicki wobec innowierców w Rzeczypospolitej czasów saskich. Problemy ujednolicania $w$ społeczeństwa w państwie wielonarodowym $i$ wielowyznaniowym, ,Kultura - Historia - Globalizacja", 5/2009, s. 107-118.

Trajdos T.M., Krakowscy „,markowie” za panowania Władysława II Jagietly (1386-1434), „Studia Historyczne”, 25/1982, nr 3-4, s. 371-386.

Trajdos T.M., Najstarsze fundacje dla kanoników regularnych od pokuty $w$ diecezji wileńskiej, „Nasza Przeszłość”, 119/2013, s. 21-66.

Włodarski B., Chronologia polska, Warszawa 1957.

Wojtkowski J., Konwertyci w kronice jezuitów malborskich 1647-1744, w: Jezuici w Malborku a życie religijne na terytorium diecezji pomezańskiej w okresie nowożytnym, red. J. Hochleitner, Malbork 2014, s. 121-132. 